\title{
INVESTING IN OIL AND GAS DRILLING FUNDS
}

\author{
ROBERT A. BROWN*
}

\begin{abstract}
Since investment in the oil and gas business entails high risk, there is a broad range of matters to be considered before investing in an oil or gas drilling fund. This paper discusses a range of such factors, including types of drilling fund opportunities; fund objectives and the interaction of risk and return; how to calculate the economics of a drilling prospect; fund management; and tax implications.
\end{abstract}

\section{INTRODUCTION}

The subject of this paper is "investing in oil and gas drilling funds". The term "drilling fund" is used to cover all the different mixes of oil and gas investments available thorugh fund vehicles-ranging from wildcat exploration prospects, through development or off-set drilling situations, and on to the straight purchase of producing oil and gas properties. The title of the paper is somewhat a misnomer, for the range of drilling funds available to the investor today includes both "investments" and "speculations". Benjamin Graham, the dean of security analysts, attempted to differentiate between an "investment" and a "speculation" as follows: "An investment operation," he said, "is one which on thorough analysis promises safety of principal and an adequate return. Operations not meeting these requirements are speculative." This distinction, originally developed in relation to the stock market, has particular application to investments in the oil and gas field. For simplicity, however, the term "investor" is used to include both "investors" and "speculators". The difference between the two should, however, constantly be borne in mind.

It is perhaps trite to say that the oil and gas industry is a high risk business. Certainly, a surface glance at the industry track record could lead the unsuspecting investor to the incorrect conclusion that the odds of success in the oil and gas business are not that bad at all. Figure 1 summarizes the 1975 statistics for drilling completions in Alberta. These statistics reflect a $43 \%$ success ratio on all exploratory drilling and an $86 \%$ success ratio on development drilling. The statistics should, however, be viewed in the following light:

-First, the completion of a well does not mean that it is a commercial success and that the owner will recover all his drilling costs plus a reasonable profit. Normally, economics dictate that a well be completed provided the well will return more than the costs of completion (excluding the drilling costs).

-Secondly, the statistics include shallow gas wells, many of which should not be included in the exploratory well category.

-Thirdly, as the probabilities of drilling a successful new well are based primarily upon judgment, projecting the future from historical results is not usually helpful.

Further insight into the riskiness of the oil and gas business can be gained by reviewing, in very general terms, how a drilling prospect is developed and brought to the market place. A simple example should

- B.Comm, C.A., Partner, Thorne, Riddell \& Co., Calgary, Alberta. 
FIGURE 1

\begin{tabular}{|c|c|c|c|c|}
\hline & Oil & Gas & $\begin{array}{l}\text { Abandoned } \\
\text { (Suspended) }\end{array}$ & Total \\
\hline $\begin{array}{l}\text { New field wildcats } \\
\text { New pool wildcats } \\
\text { Deeper pool tests }\end{array}$ & $\begin{array}{l}12 \\
45 \\
10\end{array}$ & $\begin{array}{r}100 \\
292 \\
36\end{array}$ & $\begin{array}{l}238 \\
361 \\
140\end{array}$ & $\begin{array}{l}350 \\
698 \\
186\end{array}$ \\
\hline Shallower pool tests & $\overline{1}$ & $\overline{\pi c}$ & - & - \\
\hline Outposts & 14 & 76 & 49 & 139 \\
\hline Total exploratory tests & 81 & 504 & 788 & 1,373 \\
\hline Stratigraphic tests & $-\overline{0}$ & $=$ & 10 & \\
\hline Development wells & 589 & 1,454 & 325 & 2,368 \\
\hline $\begin{array}{l}\text { Service wells } \\
\text { Potash wells }\end{array}$ & $\overline{-}$ & $\overline{-}$ & $\overline{-}$ & 81 \\
\hline Miscellaneous wells & - & - & - & 6 \\
\hline Total & 670 & 1,958 & 1,123 & $\overline{3,838}$ \\
\hline
\end{tabular}

Source, Canadian Petroleum Association, Statistical Yearbook 1975.

assist the investor in comprehending the nature and types of variables involved, and the resulting risks. Briefly, to determine the existence of a commercial oil reservoir, a geologist must predict that all the necessary conditions are likely to be present. Predicting these conditions is somewhat akin to astrology. The geologist does, however, have a number of effective techniques for determining what lies unseen below the surface of the earth. Notwithstanding all the sophisticated techniques available to the geologist, the existence of an oil reservoir must still be determined by analogy. In other words, the geologist must know that similar conditions in other areas have produced oil. He must guess what geologic forces produced a given formation and analogize as to whether such forces have produced a commercial hydrocarbon reserve reservoir beneath the specific prospect. He must then determine the most likely field size, which is calculated as the product of pay thickness (net pay), a recovery factor (recovery per foot) and areal extent (productive area). An error in judgment on any of these three factors can substantially affect the economics of the venture.

Because a geologist can only make predictions, there is always risk in the drilling of a well. Having determined the potential existence of hydrocarbons and the field size parameters, attempts are then made to quantify the amount of drilling risk. This is normally accomplished by listing the possible outcomes and the profit levels associated with each outcome with respect to the particular exploratory well. Based upon past experience, expert judgment, statistical analysis, and often computer simulation, the geologist then determines the appropriate probabilities for the various outcomes. Next, all of this information is assembled numerically in a "payoff table" or graphically in a "lottery diagram", to reflect the possible outcomes, the probabilities that these outcomes will occur and the pay-offs related to each probability. Finally, the geologist determines the "expected value" of the particular prospect with other ventures by multiplying the value of each outcome by the probability of its occurrence, and aggregating the results (Figure 2). While many exploration companies stop at this point, a number of different techniques (such as the new risk analysis developed by the Wharton School, University of Pennsylvania) have been developed to further refine the 
FIGURE 2

\section{PAYOFF TABLE}

$\begin{array}{lrccc}\begin{array}{c}\text { Possible } \\ \text { Outcomes }\end{array} & \text { Reserves } & \text { Probability } & \text { Payoff (M\$) } & \begin{array}{c}\text { Expected } \\ \text { Value }\end{array} \\ \text { Dryhole } & \text { 0 BCF } & 0.71 & (262) & (186) \\ \text { Minimum } & 30 \mathrm{BCF} & 0.09 & (85) & (8) \\ \text { Most likely } & 100 \mathrm{BCF} & 0.18 & 1,583 & 285 \\ \text { Maximum } & 400 \mathrm{BCF} & 0.02 & 6,570 & \underline{131} \\ \quad \text { Expected value } & & & & \underline{222}\end{array}$

Note: Expected Value $=$ Probability $\times$ Payoff

Source, An Introduction to Exploration Economics, R. E. Megill.

ranking of projects in relation to their relative risk. In looking at the posible outcomes or payoffs, however, it is emphasized that every amount reflected therein is an estimate. While some of the estimates can be more accurately predicted than others (for example, the cost of the worst possible outcome, a dry hole, is more easily estimated than the discounted cash flow arising from various degrees of success), the guesstimate which has the greatest effect on the selection of a prospect is the probability attached by the geologist that its outcome will be successful.

Where the geologist ascribes a particular probability to the successful outcome of a prospect, the validity of statistical probability operates only when a number of prospects are involved. For example, if the geologist predicts that with a specific prospect there is a $25 \%$ probability of successful outcome, this statistical probability will not necessarily be proved by drilling only four wells. An exploration program should therefore include a sufficient number of prospects to provide a basis for probability planning. In summary, the predictions of the geologist based upon his intuition, judgment and past experience are paramount to the selection of appropriate prospects for exploratory drilling. Due to the numerous variables involved and the substantial differences in possible outcomes which result where adjustments are made to the variables, the risk to the investor in exploratory drilling is extremely high. As the Canadian taxation system, unlike that in the United States, has not provided adequate incentives to compensate for the risk inherent in such ventures, individuals and non-principal business taxpayers in Canada have not, at least until recent times, found drilling funds attractive investment opportunities.

The year 1976 heralded a renewal of interest in oil and gas drilling ventures. There are several reasons for this. The May 25, 1976 Budget provided the major stimulant of investor interest. The Budget contained significant changes in the tax deductibility of monies spent in exploration activities. Specifically, both individuals and corporations may now write off $100 \%$ of all "Canadian exploration expenses" incurred in a particular year against income from any source. Thus, unlike most other investments, all of the monies expended on exploration activity may now be immediately deducted by the investor for income tax purposes. This permits the sheltering of other sources of income, such as salary, from current taxes otherwise payable. With the taxation authorities progressively eliminating the tax advantages of leveraged leasing and other tax sheltering techniques, high-bracketed taxpayers have found 
their scope for income tax deferral restricted and thus have begun to reexamine the higher risk areas such as oil and gas investments. From a slow start in 1976, caused in part by delays in passing the Budget proposals into law, a great many drilling fund opportunities have now reached the marketplace. Many more, currently in various stages of preparation, will surface in the near future.

From an investment viewpoint, the ownership of oil and gas assets provides a reasonable hedge against the diminishing value of the dollar caused by inflation. Many people feel that inflation will continue and that the value of oil as a commodity, especially in light of its high current and predictable future demand, will keep pace with the inflation rate. For such investors, oil and gas properties represent an "inflation-proof" future revenue stream.

While it may not be essential for the investor to be an expert in the oil and gas industry to analyze drilling fund opportunities, a basic understanding is essential if he is to avoid the many pitfalls inherent in such investments and arrive at a reasonably informed business decision. In this regard, the situation facing the prospective drilling fund investor is analogous to that faced by the investor in the stock market. The economic integrity of an investment in a drilling fund will largely depend upon the investor understanding at least the rudiments of the industry. Preferably, the investor should know substantially more. If he is not prepared to devote the time and effort necessary to become knowledgeable in this area, or alternately, if he is unwilling to pay for expert advice, he should not invest in the oil and gas business. Many investors have neither the time nor the inclination to acquire a detailed current knowledge of the industry, the present economics of the particular areas in which prospects are available, industry drilling success ratios, and other relevant data. In these circumstances, the professionally managed drilling fund provides the answer, for its appealing features to the oil and gas investor are precisely the same as those which popularized the mutual funds in the securities field: professional management, economies of scale, and the ability to spread risk over a large number of prospects. If the investor wants the assurance that full disclosure as required by the securities commission has been given, he should participate in a publiclyoffered drilling fund. On the other hand, if he feels reasonably comfortable with his knowledge of the oil and gas industry or knows the people involved, a private fund could also be considered.

The balance of this paper is addressed to the drilling fund investor: his objectives, the types of investments available to him, economic analysis of fund investments, and the major factors to be considered prior to investing in a drilling fund.

\section{INVESTOR OBJECTIVES}

The types of investment opportunities in drilling funds vary enormously. Generally speaking, however, they fall into four basic categories:

\section{(a) The Exploration Fund}

A substantial portion of the monies spent by such funds will be used either in the search for an undiscovered pool of oil or gas, or drilling in areas with the hope of greatly extending the limits of an already developed pool. 
(b) The Development Drilling Fund

These funds spend the major portion of their resources in drilling wells in the same reservoir as other producing wells on a particular lease or prospect or in drilling on an offset lease usually not more than one location away from a well producing from the same reservoir.

\section{(c) The Production Purchase Fund}

These funds pool investor monies for the purchase of producing oil and gas properties. Properties purchased normally contain "proved reserves", that is, quantities of crude oil, natural gas, and natural gas liquids which, upon analysis of geologic and engineering data, appear with reasonable certainty to be recoverable in the future from known oil and gas reservoirs under existing economic and operating conditions.

\section{(d) The Balanced Fund}

Such funds include both exploratory and development drilling, as well as the acquisition or producing oil and gas properties. They thereby provide the investor with an integrated investment.

There are a number of different basic types of oil and gas drilling fund opportunities. In addition, different fund managers will ascribe either a general overall objective or a specific objective to their particular fund. For example, a fund may be formed for the purpose of drilling development wells in certain specific areas, or to search for oil, natural gas, or both oil and natural gas in either a general or a specified geographic area. As can be expected, the degree of risk inherent in any particular program depends upon its basic type (exploration, development, production, or balanced) and the specific objectives of the fund. As a general rule, the profit potential is reduced proportionate to the risk. It is therefore extremely important from the investor's viewpoint that he select a fund which has objectives that most closely fit his own particular criteria. Such criteria include: his knowledge of the industry, the level of risk which he is willing to accept, the return on investment (ROI) which he expects to achieve, and his ability to utilize tax losses arising from his investment to reduce taxes otherwise payable on income from other sources.

The investor should be prepared, especially where he is entertaining an investment in an exploration or development drilling fund, to spread his investment over several years, rather than have all of his funds invested and spent in one particular year. Not only does this deferred timing facilitate superior technical planning by the fund manager; it also reduces the tendency to concentrate upon short term goals such as the spending of monies before the end of the first year. Programmed investment also enables the fund manager to achieve reasonable and planned diversification. It is diversification (reduced participation in a larger number of prospects) that is the key to lowering the odds against the investor in oil and gas exploration. Sharing reduces risk. Simply stated, smaller shares have smaller expected values but they also have smaller worst outcomes. Thus, the sacrifice of some portion of the expected value reduces the investor's risk. The higher the risk, the smaller should be the share taken by the investor. The investment axiom "it is alright to put all of your eggs in one basket provided you watch the basket" is not relevant when applied to the oil and gas fund area.

Finally, in making an investment in a particular drilling fund, the 
investor must consider what the chances are that he may lose all or a portion of his investment. Drilling funds are not an area for the "widow and orphan" type of investor. A person contemplating an investment in a drilling fund must be prepared to lose all or a portion of his investment. In this regard, it is instructive to note that the North American Securities Administrators Association requires investors in U.S. public oil and gas drilling funds to meet certain "suitability standards" relating to their personal net worth, the standards varying with the type of fund involved. The suitability standards are such that only the more wealthy (and thus hopefully more sophisticated) players can join in the game.

Oil and gas drilling funds can be packaged in a variety of different wrappings. Generally speaking, however, they are available in the following formats:

\section{(a) Limited Partnerships}

In a fund which takes the limited partnership form, the party with oil and gas expertise becomes the general partner, with full managing authority over the affairs of the fund, and the investor becomes a limited partner. As such, the investor's liability is limited to the amount of his investment in the partnership; however, to achieve this limited liability position he must forego any involvement in the day-to-day affairs and operations of the fund. Most oil and gas drilling fund arrangements take the limited partnership form. Examples of such funds include the Sabre Resource Program and the Ranchmen's Exploration \& Development Partnership (1976).

\section{(b) "Panarctic" Structure}

The Income Tax Act provides that where an investor incurs exploration and development expenditures in return for shares of a corporation, he may under certain circumstances deduct these expenditures for income tax purposes, notwithstanding that the results obtained therefrom accrue to the benefit of the corporation involved. An example of this type of structure is the recent Rangeco Oil and Gas Ltd. fund.

\section{(c) Hybrid Programs}

A number of complex structures have been created to fit the specific needs of an explorationist and certain investors. They range in form from the German financing to the so-called "guaranteed" financing. The selection among the various alternate structures available depends primarily upon the income tax and legal liability preferences of the particular investor.

\section{ECONOMIC ANALYSIS}

In determining the desirability of a drilling prospect, the oil and gas industry places a great deal of emphasis upon the "discounted cash flow method" for the preparation of economic analyses. The discounted cash flow (DCF) technique is discussed in detail below. A number of other techniques and rules of thumb are also applied to the results of a DCF analysis to establish the economic merits of a prospect. These tests include:

\section{(a) The Payback Test}

In practice, it is not uncommon to find oil and gas consultants applying a five or six year "pay-back" test to an oil and gas investment. 
Where, for example, the cost of a particular exploration play is $\$ 100,000$, application of the pay-back test would require that aggregate undiscounted cash flows from the prospect during its first five to six years be equal to or greater than the initial investment. A more stringent payback test is applied by certain Canadian chartered banks. For example, one particular bank requires a production loan to be repaid in five years. In addition, it requires that at least $50 \%$ of the total estimated reserves remain in the ground after the loan is paid out.

\section{(b) The Profit Ratio Test}

Another commonly used "rule of thumb" is to compare the nondiscounted cash flow (the "profit") to the cost of the investment, and to require a $2 \frac{1}{2}$ to 3 times coverage of cost. This is commonly referred to as the "profit ratio test".

\section{(c) Other Tests}

While there are numerous other tests of varying sophistication which can be and are applied to exploration prospects, the uncertainties inherent in projecting the basic cost and revenue data favour keeping one's analysis as simple as possible.

As indicated above, a number of tests relating to cash flow (discounted or undiscounted), timing and financial accounting may be used in evaluating an oil and gas investment. DCF is, however, the most commonly used technique. The purpose of DCF analysis is to provide a standard basis for comparing one investment with another. In general, a DCF is prepared by breaking out revenues and expenses on a year-by-year basis, and applying a discount factor (either on a pre- or post-tax basis) (Figure 3). The net result represents the present value of all the expected future net pre- or post-tax cash flows from the particular prospect. Where discount rates in excess of $15 \%$ are employed, cash flows arising after the tenth year do not materially add to value (Figure 4). In preparing such an analysis, it is important to note that drilling credits and similar items, together with the income tax refunds resulting from cost deductions, are treated as cash inflows and thus are aggregated with production revenues.

A further refinement of the DCF computation is the calculation of the "internal rate of return" (IRR) of the investment, that is the point where the discount rate is large enough to discount the net cash flow stream to zero. Stated differently, the IRR is the maximum interest rate which could be paid on borrowed capital and still break even on the investment. If funds can be invested at an interest rate in excess of the IRR of a prospect, the prospect should in most cases be rejected. As the IRR can only be found by a process of trial-and-error, it is usually located by computer. Alternately, a rule of thumb can be used to reduce the number of trials required to locate the IRR. For example, the IRR normally approximates the reciprocal of years to pay out, multiplied by 100 . (If the result is negative, the discount rate selected is too large.) Alternately, the number 72 can be divided by the number of years it takes to double the investment, with the result usually approximately the IRR of the investment.

In considering the results of a DCF analysis, one should bear in mind that while the final result is the same as the accounting profit (aggregate after-tax net income equals total net cash flow) DCF analysis and accounting analysis differ fundamentally in their approach to timing. 
FIGURE 3 - A TYPICAL DCF ANALYSIS

BEFORE AND AFTER INCOME TAX

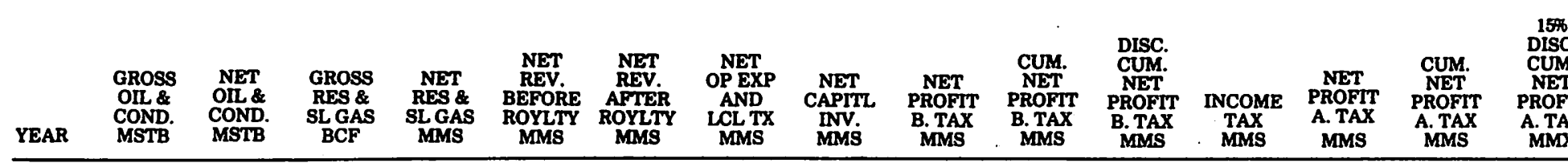

SUMMARY

INTERESTS *

INTL WORKING INT (PCT) =

INTL CAPITAL INT (PCT) =

AVG. ROYALTY INT (PCT)

RESERVES \& PROJ

LIFE (YRS) =

$\begin{array}{ll}\text { GROSS } & \text { GRESENT VALUE * } \\ \text { NET }\end{array}$

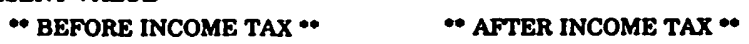

$\begin{array}{llllll}\text { DISC. OP. INC INV. PROFIT OP. INC INV. PROFIT } & \text { INC) } \\ \text { RATE } & \text { (MS) } & \text { (MS) } & \text { (MS) }\end{array}$

(MSIB) SOLN GAS RESIDUE COND. PROPANE PROPANE BUTANE SULPHUR

$\begin{array}{llllll}\text { (MSIB) } & \text { (MMCF) } & \text { (MMCF) } & \text { (MSIB) } & \text { (MSIB) } & \text { (MSTB) } \\ \text { (MSTR) } & \text { (MLT) }\end{array}$

OP. INC

(MS) PROF)

(MS)
NET PROFTT INDICATORS * RATE OF RETURN (PCT)
INTL OP INC (\$DAY)
AVG LSE OP CST (\$UNT)
AVG IS PRD VAL (\$ UNT)
UNDIS PROFTT/UNDIS INV
DIS PROFIT/DIS INV
DIS PROFIT/UNDIS INV
CAPITAL EXPOSURE (MS)
DNDISPRT
DU PRO


FIGURE 4

\section{EXCERPTS FROM PRESENT VALUE TABLE}

Present Value of $\$ 1$

$\begin{array}{ccccc}\text { Years } & & & & \\ \text { Hence } & 10 \% & 15 \% & 20 \% & 30 \% \\ 1 & .909 & .870 & .833 & .769 \\ 5 & .621 & .497 & .402 & .269 \\ 10 & .386 & .247 & .162 & .073 \\ 15 & .239 & .123 & .065 & .020 \\ 20 & .149 & .061 & .026 & .005 \\ 25 & .092 & .030 & .010 & .001\end{array}$

Accounting measures profit over a period as related to capitalized costs. As such, accounting matches booked costs against future revenues. On the other hand, DCF procedures match actual cash outflows against actual cash inflows.

When presented with a DCF economic evaluation, the investor usually cannot help but be impressed with the precision and content of the computer print-out. Often, an investor will accept the computerized data at face value. The intelligent investor will, however, take the time to investigate and question the data input behind certain of the major items contained in the economic analysis, since variations in any of the major input data can have a substantial effect upon the projected present value of the particular prospect. At a minimum, the following areas should be critiqued.

\section{(a) Production Volumes}

Errors in the estimated date of commencement of production or the projected amount of annual production can have a material effect on the total value of a prospect. The investor should ensure that the predicted volumes are realistic in light of the type of production contemplated, the area in which it is located, the proximity to pipelines, and the effect upon production levels of government regulations. The production rate, pressures, and gas:oil:water ratios can change drastically in the early life of a well. A perfect example is the decline rates which developed in the shallow gas fields of southeastern Alberta. The investor should, therefore, bear in mind that production rates are not absolutes and be prepared for changes both for the better and for the worse. The investor should also be aware that from an economic viewpoint, wells are not normally produced wide open.

\section{(b) Pricing}

Another key variable is the pricing schedule used in preparing the DCF. Petroleum engineers in both industry and private consulting areas have differing levels of optimism concerning levels to which oil and gas prices might go in the future. It is a fact of life that different consulting reports are looked upon with different degrees of reliability and that knowledgeable purchasers apply factors of 0.5 to 1.5 to economic analyses, depending upon the particular petroleum engineer involved. Generally speaking, however, in arriving at their projected annual prices for oil and natural gas, most consultants have assumed that the present price for Canadian crude will rise over a certain period of time to the present world crude oil price. 
In determining the rate of price escalation, consideration is given to all current indications of future government actions which might affect prices, At least one consulting firm has provided for a large price increase in 1985 due to their belief that at that time a substantial portion of the gas on the market will be Arctic gas, with a high production and transportation cost content.

Many poor investments made prior to 1972 have had successful outcomes due entirely to the substantial price changes which have occurred since that time, for example, gas prices have risen from $\$ 0.16$ to $\$ 1.22$ per M.C.F. It remains to be seen whether governments will in future permit the producer to participate fully in price increases. It is probable that the producer's share of future price increases will not be as great as it has been to date.

The investor should also bear in mind that as the finding cost and price of oil increases, the possibility of inter-fuel competition becomes more relevant. There is, at some price level, a point where other fuels such as coal or nuclear energy become both economic and competitive with oil and gas. It cannot be assumed that prices for oil and gas will increase indefinitely.

Finally, it should be noted that the price of crude oil depends on its quality (gravity) and geographical location. Another factor affecting the price is whether the crude has a paraffin base, an asphalt base, or a mixture of these two bases. In addition there is a different pricing schedule applied to "old" and "new" oil. The quality of natural gas is a consideration where price is the issue. The more energy a cubic foot of gas is capable of producing, the higher the price it commands. The heating characteristic of gas is expressed in British Thermal Units (BTU's) per cubic foot. Gas is normally sold under long term contracts and its production depends on consumer demand and is often seasonal. The investor should therefore ensure that the price schedule used relates to the type of oil or gas expected from the particular prospect.

\section{(c) Quantum of Investment}

In determining the return on investment (ROI), the income tax deductions relating thereto should be netted against the original cash outflow to determine the net amount of the investment. In addition, amounts received relating to various provincial government incentive schemes such as the Alberta Drilling Incentive Credit, Seismic Exploration programs and the Small Explorers Credit should also be taken into account in determining the net amount at risk. Where, for example, an investor in the $60 \%$ tax bracket spends $\$ 100,000$ on drilling an exploratory well, he may reduce income taxes otherwise payable with respect to his other income sources by $\$ 60,000$. If he earns $\$ 30,000$ in drilling credits on the well, his net investment, after income tax reductions and drilling credits, is $\$ 10,000$.

It should be mentioned that the recent tax changes have placed individuals in the highest marginal tax bracket $(60 \%)$ at a competitive advantage with corporate taxpayers at the maximum corporate tax rate $(47 \%)$, where the acquisition of oil and gas properties or the spending of development drilling monies are concerned. The advantage relates to the $13 \%$ tax rate differential applied to the cost of the properties or to the amount of development drilling involved.

While income tax effects are an important input to the overall DCF 
analysis, income tax should not dictate whether an investor makes a particular investment. Such a decision should be based upon the projected ROI and the level of risk inherent in the particular prospect. The primary consideration should be economics, not income tax benefits.

\section{(d) Other Areas}

The other items contained in a normal DCF analysis will not normally have any material effect on the rate of return derived from the particular prospect.

A common question asked by the prospective investor in a drilling fund is: "What ROI should I obtain?" Where exploration and development drilling prospects are involved, no accurate estimate can be made as to the desired rate of return. The rate of return on such prospects will depend upon the specific prospect, the probabilities for a successful outcome, and the degree of risk. As a generalized statement, the return on exploratory drilling should be greater than the return on development drilling. Development drilling should achieve a rate of return in excess of that considered satisfactory for a production purchase (in excess of 20\%). Where the purchase of a producing property is contemplated, the ROI will vary depending upon the nature of the particular properties involved. Where, for example, the property has a long production history, a $12 \%$ to $15 \%$ after-tax ROI would be considered reasonable. Where the production history is relatively short, $20 \%$ to $25 \%$ would be appropriate. Where there is no production history, a risk factor from $50 \%$ to $65 \%$ might be applied to the value otherwise determined.

When the purchase of producing properties is contemplated, it is always useful to obtain a second opinion. Most Canadian chartered banks have oil and gas departments with extensive experience, expertise and information relating to oil and gas fields in Western Canada. From a property evaluation viewpoint, the present practice within one Canadian chartered bank is to compute a DCF at the current bank lending rate (at the cost of money rate) and divide the result by two. As mentioned before, banks will often apply, in addition, a five year pay-back test on the loan and/or will require that at least $50 \%$ of the total reserves remain in the ground after the loan is paid out. Another Canadian chartered bank uses as its rule of thumb $50 \%$ of the DCF using a $7 \%$ discount rate as the starting point in determining the loan potential of a particular producing oil and gas property.

Another consideration affecting the ROI is the possibility of leveraging the investment with borrowed funds. While leveraging can increase the return on the equity portion of the investment, it also increases risk. Although banks do not normally lend monies for either exploratory or development drilling, they will advance funds, as indicated above, to facilitate the purchase of producing properties. From an income tax viewpoint, the conservative investor may be wiser to acquire producing oil and gas properties through bank financing, rather than engaging in exploratory drilling. For example, if he acquires a producing property for $\$ 100,000$ using personal equity funds of $\$ 30,000$ together with $\$ 70,000$ of bank borrowings, his write-off in the initial year is $30 \%$ of 100,000 , or $\$ 300,000$ (a 1 for 1 write-off). If he invests in a non-levered exploration drilling activity, the same personal equity investment results in a writeoff of $100 \%$ of 30,000 , or $\$ 30,000$. In both instances the write-offs are the same-but the risk undertaken is substantially different. 
For income tax purposes, an investor may only deduct exploration and development expenditures incurred with borrowed monies if he is personally liable for the debt. Where non-recourse financing has been used to incur costs, the costs cannot be deducted until the debt is actually paid. Where leverage occurs within a limited partnership, the maximum deduction for a limited partner is the lesser of his allocated share of expenses incurred by the partnership or the balance in his partnership equity account. If the limited partner wants the deductions, he must borrow the monies personally, then either advance them to the partnership or contribute them in the form of additional equity.

\section{FACTORS TO CONSIDER}

After the investor has satisfied himself respecting the economic aspects, a number of specific matters must be considered before finalizing his drilling fund investment. The major factors to be analyzed are set forth below.

\section{Management}

The most important factor for the investor to consider is the fund management-its reputation, experience and track record. When investing in a drilling fund, the emphasis should always be placed on the quality of the promoter rather than on the valuation of technical information, for rarely is sufficient technical data made available to the investor. In fact, where the fund is concentrating its efforts in the exploration sphere, the promoter himself usually has no specific idea where the funds will be spent. The promoter should have a first-rate reputation in the oil and gas industry in general, in his field of expertise in particular, and a solid reputation in the business community at large. It is up to the investor (or his professional advisor) to ensure that the people to whom he entrusts his money are qualified to manage it from the financial as well as the technical point of view. There is only one way to find out-ask around. The investor should discuss the merits of the drilling fund and its management personnel with an experienced oil and gas lawyer or accountant, the oil and gas department of a bank, oil industry executives, and independent consultants. He should ensure that the financial house (if any) promoting the program and the fund's legal and accounting advisors have excellent reputations of their own.

Enquiries should be made into the experience of the promoter and persons who will be involved with him in managing the drilling fund. The promoter group should have at least three years of relevant oil and gas experience and preferably more. If any managerial responsibility for the drilling fund is to be rendered by someone other than the promoter, the experience and background of that person (or persons) should be investigated. Again, information relating to the experience of such persons will be obtained through discussions with various oil and gas industry people.

Finally, an evaluation should be made of the promoter's track record. While a good past track record does not guarantee future success, it does provide tangible evidence of the promoter's ability to perform. In analyzing the track record, the following matters should be reviewed:

-The relationship between cash distributions from previous funds to investors' contributed capital should be established. 
-An estimate of oil and gas reserves located by any previous fund should be made.

-If independent evaluations of reserves are not available, an approximate valuation should be made using the following rule of thumb for reserves in the ground:

-.254 per Mef of gas

$-\$ 2.00$ per bbl of oil

The results should then be compared with the initial investment to determine the rate of return achieved.

-Where undiscounted annual revenue or cash flow information is available, it should be compared with the initial investment; and the IRR and the profit ratio of the program should be determined.

- The ratio of productive wells to dry holes should be established and compared with statistics for the overall industry in general and for the specific geographic area in particular. It is important to determine whether the successful wells were exploratory or development.

The importance of the reputation and track record of the promoter cannot be over-emphasized. Mackay's Law states as follows: "If you put a man with experience together with a man with money, their positions will rapidly be reversed." Once a trustworthy management group has been located, the investor should trust them completely and give them a chance to prove themselves. Results are not achieved overnight; the promoter should therefore be given several years to prove himself. As the investor is paying for the promoter's geological abilities, he should not attempt to second-guess him.

\section{Compensation}

Another important area for the investor to review is the amount of compensation the promoter is to receive for his efforts. The investor should attempt to determine whether, with respect to a particular drilling fund, the total compensation to the promoter is reasonable. This is preferable to attempting to compare promoters' compensation for a number of drilling funds. As the compensation to a promoter can take many different forms (for example, overriding royalty, carried interest, working interest, different percentage interests pre- and post-payout, back-ins, etc.), an inter-fund comparison of compensation constitutes an exercise in futility, as it does not give any indication of which fund will achieve the greatest success. It is, however, important for the investor to determine how much of his invested capital is to be used in actual drilling and exploration activities.

Compensation to the promoter usually takes two formsadministrative charges and equity participation. Where administration expenses are concerned, the investor should ensure that he pays no more than his fair share of the actual cost to the promoter of providing these services. Charges for general and administrative overhead would normally include all customary and routine legal, accounting, geological, engineering, well supervision, travel, office rent, telephone, secretarial, salaries, and other incidental reasonable expenses necessary to the conduct of the drilling fund's business. Such costs should be determined in accordance with generally accepted principles and, where material, should be subject to an annual independent audit. The investor should 
determine, at the outset, what the estimated amount of such expenses might be and whether such estimate is reasonable in relation to the services being provided. The investor should also determine whether there is a maximum limit to the amount of administrative expenses which the promoter can charge.

Having determined how much of his money is going to go into drilling and how much for overhead, the investor should then turn his attention to the equity participation taken by the promoter. The size of such participation can be very relevant to the net after-tax rate of return to the investor. Obviously, if the loading is too high, a program which achieves the simple statistical averages in terms of success may produce unacceptable rates of return. In determining what is a reasonable equity remuneration to the promoter, a good starting point is found in the North American Securities Administrators Association Guidelines for the Registration of Oil and Gas Programs, adopted in September of 1976 by that Association. While these Guidelines relate solely to publicly offered drilling funds, they at least provide the investor with a bench mark for measuring the reasonableness of a promoter's remuneration. It should be borne in mind that these Guidelines relate to U.S. drilling funds, which are normally designed to flow through to the investor all or substantially all of the income tax benefits implicit in oil and gas activity. Thus it is usual for capital expenditures (essentially leasehold and equipment costs) to be borne by the promoter, with all of the intangible drilling costs being paid for by the investor. Nevertheless, these Guidelines are a useful reference point. They provide, in part, as follows:

-Commissions payable to broker-dealers on the sale of fund units are to be paid in cash. Indeterminate consideration (for example, overrides, net profit interests, etc.) is prohibited.

-Organization and offering expenses, plus management fees, should not exceed $15 \%$ of initial capital contributions.

-Where the promoter pays all capital expenditures (leasehold and equipment costs) and participates in the fund's capital contributions to a minimum of $10 \%$, the promoter may receive $35 \%$ of fund revenues; this percentage may be increased in additional increments of $5 \%$ for each additional $5 \%$ increase in the percentage of capital contributions paid by the promoter, up to a maximum of $50 \%$ of revenues.

-Alternately, the promoter may receive $15 \%$ of revenues plus an additional percentage equal to his capital expenditures as compared to total costs (on a prospect basis), until such time as he has recovered his capital expenditures. Revenues would then be distributed $15 \%$ to the promoter and $85 \%$ to the investors until the investors have recouped their capital contributions. Thereafter, $15 \%$ plus the additional percentage would be paid to the promoter.

-In connection with other possible alternatives, a promotional interest in excess of $25 \%$ on a fund basis is not permitted. A minimum commitment by the promoter to pay at least $10 \%$ of total fund contributions is also required.

-No specific standards are included for drilling programs in which the promoter receives a subordinated or reversionary working interest, since there are two separate schools of thought on the subject. The preface to the Guidelines indicates that the difficulty 
arises in the determination of "payout", rather than with respect to revenue sharing. In regard to the latter, it is stated that "as an alternative to sharing revenues on a basis related to costs paid, it will be considered reasonable for a promoter of a drilling program to receive a promotional interest in the form of a subordinated percentage of the working interest. The holder of a subordinated working interest shall be entitled to receive his share of revenues only after payout is reached, determined on either a prospect or total program basis, and when such promotional interest is entitled to receive distribution, it shall bear costs in the same ratio as it participates in revenues. Said promotional interest shall not exceed $33-1 / 3 \%$ if determined on a total program basis, and $25 \%$ if determined on a prospect basis."

It may thus be seen that a reasonable level of compensation to a promoter approximates $25 \%$ of revenues from the outset (where the promoter has a minimum $10 \%$ equity participation in the drilling fund) and $25 \%$ of revenues after payout (where the promoter has a subordinated percentage of the working interest).

The Guidelines make the following comments concerning income or production purchase funds:

-Where a major portion of the promoter's management and operating responsibilities are performed by third parties, the cost of which is paid by the fund, the promoter may take a $3 \%$ working interest convertible to not more than a $5 \%$ working interest after the returm from production to the investors of $100 \%$ of their capital contribution computed on a total fund basis.

-Where the promoter maintains the operating capabilities and technical staff and provides a major part of the management and operating functions of the fund, the promoter may take no more than a $15 \%$ working interest.

One final area of potential "compensation" should be considered by the investor. While it is a less visible means of remuneration, it has created serious difficulties to investors in the past. This is where the promoter purchases services from affiliated organizations or where the drilling fund acquires prospects from the inventory of the promoter. The investor should determine if these activities are contemplated and should receive such assurances as he considers necessary that any such transactions will be conducted at fair market value.

\section{Comfort Criteria}

After the investor has satisfied himself as to the economics of the program, the integrity of its management, and the amount which he is paying for management expertise, there are a number of additional criteria which, if met by the particular drilling fund, give the investor further "comfort" that his monies will be properly managed. These include the following:

-Size of Promoter

The financial condition of the promoter should be commensurate with any financial obligations assumed by it relating to the drilling fund. In addition, the size of the geological, engineering and financial staff of the promoter should be reasonable in relation to the size of the particular drilling fund. Where the promoter is a public company, the investor should obtain and review the audited 
financial statements of the company. In this connection, the company's annual report will often provide information relating to its success in the oil and gas business.

-Income Tax Ruling

Where the income tax consequences are important to the investor he should determine whether or not a legal opinion or an Advance Income Tax Ruling from Revenue Canada Taxation has been obtained. If not, he should have the promotional material reviewed by his accounting and legal advisors. A great deal of effort is usually avoided if an Advance Income Tax Ruling has been obtained by the promoter.

-Reporting

The investor should determine the nature and timing of reports which he will receive from the promoter respecting his investment. Normally, the investor should receive information relating to the number of gross and net wells drilled, both oil and gas, both exploratory and developmental and both successful and unsuccessful. On an annual basis, he should receive details regarding the total oil and gas proven reserves of the program, the dollar value thereof at then existing prices based upon engineering reports prepared by a qualified independent petroleum consultant, and an estimate of the present worth of such reserves.

The investor should also receive audited financial statements prepared in accordance with generally accepted accounting principles and a schedule describing each geological prospect in which the program owns an interest. Finally, the investor should receive on a timely basis such income tax information as is necessary to enable him to prepare his income tax return.

- Promoter Contributions

Additional comfort will be derived by the investor where the promoter contributes his own funds alongside those of the investor, the amount of comfort rising in direct proportion to the percentage of participation in the drilling fund taken by the promoter. Promoter participation of $10 \%$ should provide a satisfactory degree of confidence to the investor; it would, however, be somewhat unusual if the promoter contributed on a rateable basis more than $25 \%$ of the total capital contributions of the drilling fund.

A further degree of comfort is given where the arrangement provides that the investor has the opportunity to participate in everything the operator is doing without any pre-selection process. In general, the investor should ensure that he will benefit on an equal basis with the promoter in the results of any findings relating to the spending of monies contributed by him.

Where equity participations are concerned, the investor can derive a fair degree of comfort in the knowledge that the promoter will profit only if he does.

-Conflicts of Interest

The investor should be aware of any potential conflicts of interest between the drilling fund and the promoier (or an affiliate of the promoter). Many of the matters outlined above will help to reduce the potential detriment to the investor from conflicts of interest. Perhaps the key is the reputation of the promoter. The investor can 
reasonably assume that a promoter will not damage his reputation solely to raise monies for a drilling fund.

-Liquidity

As indicated above, many of the oil and gas drilling funds are structured as limited partnerships. One major drawback to the limited partnership form is that partnership interests are, generally speaking, illiquid investments, requiring the investor to realize upon his investment over the long term. The investor should be aware that a partnership can be structured from the outset to spin off an investor's percentage interest in partnership assets to him in kind on a tax-free basis. Alternately, the partnership agreement can provide for his share of the assets to be sold by the partnership with the proceeds of sale to be distributed to him. Where it is important to the investor that his investment, at some point in the future, be realizable in cash, he should look for limited partnerships with these built-in provisions. A further possibility to be noted is the conversion of a limited partnership to a Canadian corporation, followed by a listing of its shares on a Canadian stock exchange. Such potential was incorporated in the Canadian Oil \& Gas Fund (1975) limited partnership. Finally, the promoter, if a public company, could agree under certain circumstances to exchange its share for partnership interests held by the investor. While this possibility does not exist in the United States due to their income tax laws, there would not appear to be any reason why such a provision could not be used in Canada. Where such provisions are contained in the agreements, the investor should ensure that the manner in which his interest will be valued by the promoter for purposes of a take-out is reasonable and fair.

\section{CONCLUSION}

Investing in oil and gas drilling funds is a high-risk business activity. The investor should either be personally knowledgeable in the oil and gas area or should seek the advice of professional experts. He should select the type of drilling fund investment that suits his particular risk-reward requirements in the knowledge that profit potential generally lessens proportionately to the risk. The major factor in selecting a drilling fund is fund management; however, many other factors ranging from economics to comfort criteria should be looked at as well. Finally, it remains to be seen whether the tax changes will stimulate the typically conservative Canadian individual to commit substantial funds in the aggregate to the search for oil and gas reserves. It would seem that a substantial educational process must take place if such investors are to make the transition from the share, bond and real estate investiment markets to oil and gas drilling funds. It is the personal view of the writer that as time moves on, individual investors will gravitate towards balanced or production purchase funds, while the main participants in the exploration and development drilling area will be corporate investors. 


\section{APPENDIX I \\ REFERENCES}

Adams, Oil and Gas-The new Investors, paper presented to the Petroleum Accountants Society of Western Canada, (March 1977).

Brown, Oil and Gas Equity Financings, a paper presented at the Canadian Tax Foundation Annual Conference, (1976).

Cozzolino, Management of Oil \& Gas Exploration Risk, seminar sponsored by the Wharton School, University of Pennsylvania, (1977).

Graham, The Intelligent Investor, (1973) (Harper \& Row).

Hugo, Oil and Gas Drilling Funds, (1976).

MacKay, Oil and Gas, The Canadian Mining and Metallurgical Bulletin, (May 1976).

Megill, An Introduction of Exploration Economics, (Petroleum Publishing Company, Tulsa, 1976).

Newendorp, Decision Analysis for Petroleum Exploration, (Petroleum Publishing Company, Tulsa, 1976).

Ronai, Black Gold and Gas Speculation, (Prentice-Hall Inc., 1975).

Stone, Oil and Gas Investment: Tax and Economic Considerations, (Viewpoint, 1973).

Canadian Petroleum Association Statistical Yearbook, (1975).

Guidelines for the Registration of Oil and Gas Programs, (adopted by the North American Securities Administration Association, September, 1976). 